\title{
Screening of wild type Streptomyces isolates able to overproduce clavulanic acid
}

\author{
Daniela A. Viana Marques ${ }^{1}$, Valéria de Carvalho Santos-Ebinuma ${ }^{2}$, \\ Patrícia Maria Sobral de Oliveira ${ }^{3}$, Gláucia Manoella de Souza Lima ${ }^{4}$, \\ Janete M. Araújo ${ }^{4}$, José L. Lima-Filho ${ }^{5}$, Attilio Converti ${ }^{6}$, \\ Adalberto Pessoa-Júnior ${ }^{7}$, Ana L.F. Porto ${ }^{1}$ \\ ${ }^{1}$ Departamento de Morfologia e Fisiologia Animal, \\ Universidade Federal Rural de Pernambuco, Dois Irmãos, PE, Brazil. \\ ${ }^{2}$ Departamento de Bioprocessos e Biotecnologia, Escola de Ciências Farmacêuticas, \\ Universidade Estadual Paulista "Júlio de Mesquita Filho", Araraquara, SP, Brazil. \\ ${ }^{3}$ Department of Antibiotics, Universidade Federal de Pernambuco, \\ Campus Universitário, Recife, PE, Brazil. \\ ${ }^{4}$ Laboratorio de Biotecnologia, Universidade Federal de Pernambuco, \\ Campus Universitário, Recife, PE, Brazil. \\ ${ }^{5}$ Department of Civil, Chemical and Environmental Engineering, University of Genoa, Genoa, Italy. \\ ${ }^{6}$ Departamento de Bioquimica e Tecnologia Farmacêutica, Universidade de São Paulo, \\ São Paulo, SP, Brazil.
}

Submitted: July 1, 2013; Approved: March 14, 2014.

\begin{abstract}
The selection of new microorganisms able to produce antimicrobial compounds is hoped for to reduce their production costs and the side effects caused by synthetic drugs. Clavulanic acid is a $\beta$-lactam antibiotic produced by submerged culture, which is widely used in medicine as a powerful inhibitor of $\beta$-lactamases, enzymes produced by bacteria resistant to antibiotics such penicillin and cephalosporin. The purpose of this work was to select the best clavulanic acid producer among strains of Streptomyces belonging to the Microorganism Collection of the Department of Antibiotics of the Federal University of Pernambuco (DAUFPE). Initially, the strains were studied for their capacity to inhibit the action of $\beta$-lactamases produced by Klebsiella aerogenes ATCC 15380. From these results, five strains were selected to investigate the batch kinetics of growth and clavulanic acid production in submerged culture carried out in flasks. The results were compared with the ones obtained by Streptomyces clavuligerus ATCC 27064 selected as a control strain. The best clavulanic acid producer was Streptomyces DAUFPE 3060, molecularly identified as Streptomyces variabilis, which increased the clavulanic acid production by $28 \%$ compared to the control strain. This work contributes to the enlargement of knowledge on new Streptomyces wild strains able to produce clavulanic acid by submerged culture.
\end{abstract}

Key words: clavulanic acid, $\beta$-lactamases inhibitor, Streptomyces screening, submerged culture, growth kinetics.

\section{Introduction}

In spite of the antibiotics efficiency in the treatment of infections, the indiscriminate use of these compounds promoted an inevitable microbiological resistance (Spratt,
1994). One mechanisms of resistance shown by a variety of Gram-positive and Gram-negative bacteria is their ability to produce $\beta$-lactamases, enzymes that hydrolyze the $\beta$-lactam ring of penicillins and cephalosporins disabling them (Bush et al., 1995).Several preventive measures have been

Send correspondence to D.A.V. Marques. Department of Animal Morphology and Physiology, Federal Rural University of Pernambuco, Av. Dom Manoel de Medeiros s/n, 52171-900 Dois Irmãos, PE, Brazil. E-mail: daniela_viana@yahoo.com.br. 
taken to avoid the onset of antibiotic resistance, but still there is an urgent demand for new antimicrobial agents and new strategies to combat resistant pathogens (Hassan et al., 2012). One way to overcome the antibiotic resistance of many bacteria is the introduction of novel $\beta$-lactams and the combination of classical penicillin with clavulanic acid (CA), a $\beta$-lactamase inhibitor (Líras and Martín, 2009). For instance, Augmentin ${ }^{\mathrm{TM}}$ is a synthetic drug that contains $\mathrm{CA}$ and amoxicillin (Santos et al., 2011).

Actinomycetes are the most important group of antibiotic producers, and the genus Streptomyces, which is represented in the nature by a large number of species and varieties that differ in morphology along with physiological and biochemical activity, increases the economic importance of this group (Taddei et al., 2005).

Overall, the productivity of microbial metabolites is closely related to the submerged culture process. Among the important variables for the process, types of nutrients, their concentrations and operating conditions have different effects on the accumulation of metabolites, which is mainly controlled by intracellular effectors (Kirk et al., 2000; Gouveia et al., 2001; Chen et al., 2002). Therefore, the selection of the most suitable medium composition is of primary importance to increase the productivity and decrease the cost of any bioprocess (Ortiz et al., 2007).

Although CA is produced by several species of Streptomyces (Butterworth, 1984), its industrial production is almost entirely dependent on S. clavuligerus cultivation in complex medium (Silva et al., 2012). In view to produce clavulanic acid by $S$. clavuligerus, several components of industrial culture media such as starch and other carbohydrates are not essential (Efthimiou et al., 2008), therefore alternative carbon sources are evaluated to synthesize this antibiotic. Lee and Ho (1996) obtained the highest productivity employing palm oil as carbon source, but other carbons sources such as maltose and dextrin were successfully employed (Pruess and Kellett, 1983). Mounir et al. (2010) reported that the use of olive oil as the only carbon and energy source could be a promising strategy for CA production by this species. Several studies are reported in the literature on the use of different nitrogen sources for CA production, among which bacteriologic peptone (BelmarBeiny and Thomas, 1991), glutamic acid, ornitine or arginine and histidine (Romero et al., 1984), soybean flour or soybean extract (Mayer, and Deckwer, 1996), and Samprosoy $90 \mathrm{NB}$, a protein hydrolyzate from soybean (Gouveia et al., 1999).

Kinetic modeling is an important tool for implementation of optimization techniques and control strategy development (Brass et al., 1997). Several studies evaluating bioprocess modeling techniques are available in the literature, and different approaches are extensively described in text books such as that of Bailey and Ollis (1986). Tarbuck et al. (1985) proposed a kinetic model based on the Monod equation to describe CA production by $S$. clavuligerus; but it showed poor fitting to the experimental data. Baptista Neto et al. (2000) also utilized a Monod-type kinetic model to describe batch experimental data obtained using simultaneously peptone, soybean flour and Samprosoy $90 \mathrm{NB}$ as nitrogen sources. For cultivation in peptone-containing medium, a pseudo-stoichiometric equation was proposed for cell growth; however, it was not possible to propose any stoichiometric equation for CA biosynthesis because the fraction of substrate converted into product was not available. Thus, additional kinetic efforts are needed to better elucidate CA production vs. cell growth.

On the basis of this background, 19 different Streptomyces strains were screened in this study, employing two different antimicrobial activity methods, for their ability to produce $\beta$-lactamases inhibitors in different culture media. Among these, five strains showed the largest $\beta$-lactamases inhibition zones; therefore, they were selected to investigate CA production in batch submerged culture, whose results were compared with those obtained with S. clavuligerus ATCC 27064, which was selected as a standard producer. Kinetic parameters of growth and CA production as well as yield coefficients were used to investigate the process.

\section{Materials and Methods}

\section{Reagents}

Potassium clavulanate from Streptomyces clavuligerus and imidazole were provided by Sigma Aldrich (São Paulo, Brazil). All the other reagents wereof analytical grade.

\section{Microorganisms maintenance and screening media}

Nineteen different Streptomyces spp. strains isolated from soil were provided by the Microorganism Collection of the Department of Antibiotics of the Federal University of Pernambuco (DAUFPE), Recife-PE, Brazil. They are going to be called DAUFPE-3004, DAUFPE -3006, DAUFPE-3007, DAUFPE-3009, DAUFPE-3012, DAUFPE-3016, DAUFPE-3018, DAUFPE-3036, DAUFPE-3053, DAUFPE-3060, DAUFPE-3061, DAUFPE-3094, DAUFPE-3095, DAUFPE-3098, DAUFPE-3125, DAUFPE-3126, DAUFPE-3131, DAUFPE-3132 and DAUFPE-3133. On the other hand, $S$. clavuligerus ATCC 27064 was used as a control strain for comparison purposes.

Klebsiella aerogenes ATCC 15380, a well-known $\beta$-lactamase producer, was used as target microorganism to test the antimicrobial activity. It was maintained in nutrient broth composed of $(\mathrm{g} / \mathrm{L}) 10.0$ peptone, 3.0 beef extract, 5.0 $\mathrm{NaCl}, \mathrm{pH}$ 6.9-7.0. All Streptomyces strains and $K$. aerogenes ATCC 15380 were maintained at $4{ }^{\circ} \mathrm{C}$ on malt/yeast extract and nutrient agar plates, respectively, and stored in tubes $(10 \% \mathrm{v} / \mathrm{v}$ glycerol $)$ at $-70{ }^{\circ} \mathrm{C}$. The screening media were a) ISP-1 (Pridham and Gottlieb, 
1948) composed of ( $\mathrm{g} / \mathrm{L}$ distilled water) 5.0 tryptone, 3.0 yeast extract, $\mathrm{pH}$ 7.0-7.2; b) Tryptone Soy broth (TSB) composed of ( $\mathrm{g} / \mathrm{L}$ distilled water) 17.0 hydrolyzed casein, 3.0 hydrolyzed soybean flour, $5.0 \mathrm{NaCl}, 2.5 \mathrm{~K}_{2} \mathrm{HPO}_{4}$, 2.5 glucose, $\mathrm{pH} 7.0$. The seed medium used for most of the strains was ISP-1 supplemented with TSB, with the exception of DAUFPE-3006 and DAUFPE-3053 for which only TSB was used and of DAUFPE-3061, DAUFPE-3126, DAUFPE-3131 and DAUFPE-3133 for which only ISP-1 was used.

\section{Antimicrobial activity tests}

The antimicrobial activity of all Streptomyces strains was initially explored by the agar block method. To this purpose, cylindrical pieces of mycelium were cut out from well grown and sporulated cultures on both Starch Casein Agar (SCA) and ISP-2 solid media. The SCA medium was composed of $(\mathrm{g} / \mathrm{L}) 10.0$ soluble starch, 0.3 vitamin free casein, $2.0 \mathrm{KNO}_{3}, 2.0 \mathrm{NaCl}, 2.0 \mathrm{~K}_{2} \mathrm{HPO}_{4}, 0.05 \mathrm{MgSO}_{4} 7 \mathrm{H}_{2} \mathrm{O}$, $0.02 \mathrm{CaCO}_{3}, 0.01 \mathrm{FeSO}_{4} .7 \mathrm{H}_{2} \mathrm{O}, 15.0$ agar, while the ISP-2 one of $(\mathrm{g} / \mathrm{L}) 4.0$ yeast extract, 10.0 malt extract, 4.0 glucose, 15.0 agar (Pridham et al., 1957). Nutrient agar (NA) was the culture medium for antimicrobial tests using $K$. aerogenes ATCC 15380 as target. The blocks were placed on Petri dishes with $10 \mathrm{~mL}$ of NA medium containing $10 \mu \mathrm{g} / \mathrm{mL}$ amoxicillin. Then, $1.0 \mathrm{~mL}$ of $K$. aerogenes ATCC15380 suspension was adjusted to McFarland turbidity No. 1 using optical density and poured on the plates (Brown et al., 1976). The plates were placed for $10 \mathrm{~min}$ at $2-8{ }^{\circ} \mathrm{C}$ to allow the antimicrobial compound to diffuse and then incubated at $37{ }^{\circ} \mathrm{C}$. After $24 \mathrm{~h}$ of incubation, the antimicrobial activity was measured as the growth inhibition zone diameter $(\mathrm{mm})$.

The strains selected by the agar block method were then subject to further screening of the highest clavulanic acid (CA) production by the filter paper disk method. For this purpose, $500 \mathrm{~mL}$ Erlenmeyer flasks containing $50 \mathrm{~mL}$ of each medium described in Table 1 were inoculated with $5 \mathrm{~mL}$ of the ISP-1 medium containing the selected strains and incubated in orbital shaker at $30^{\circ} \mathrm{C}$ and $6000 \mathrm{~g}$ for $96 \mathrm{~h}$. In particular, the Euromicin Production (EP) medium was modified in relation to carbon and nitrogen concentrations as indicated in the same table.

Aliquots were withdraw every $24 \mathrm{~h}$ and used in filter paper disks to conduct the antimicrobial activity tests. The K. aerogenes ATCC 15380 suspension in NA medium containing $10.0 \mu \mathrm{g} / \mathrm{mL}$ amoxicillin was distributed in Petri dishes, and, after solidification, filter paper disks with 6 $\mathrm{mm}$ diameter were soaked with $30 \mu \mathrm{L}$ of different submerged culture media and placed upon the medium surface. Petri dishes were then incubated at $37^{\circ} \mathrm{C}$, and the inhibition zone diameter was measured every $24 \mathrm{~h}$ aiming to select the Streptomyces strains able to produce and excrete CA.
Table 1 - Media used in screening experiments aiming at the production of clavulanic acid.

\begin{tabular}{|c|c|c|c|c|c|}
\hline Component $(\mathrm{g} / \mathrm{L})$ & $\mathrm{EP}^{1}$ & $\begin{array}{c}\text { Modified } \\
\text { EP }\end{array}$ & $\mathrm{G}^{2}$ & $\mathrm{SC}^{3}$ & $\mathrm{SHG}^{4}$ \\
\hline Glucose & 20 & 10.0 & - & - & - \\
\hline Soybean flour & 20 & 30.0 & - & - & - \\
\hline Glycerol & - & - & 7.5 & - & 10.0 \\
\hline Sucrose & - & - & 7.5 & & - \\
\hline Soluble starch & - & - & - & 10.0 & - \\
\hline Vitamins-free casein & - & - & - & 0.3 & - \\
\hline Soybean hydrolyzed & - & - & - & - & 30.0 \\
\hline Arginine & - & - & 4.03 & - & - \\
\hline Proline & - & - & 5.79 & - & - \\
\hline $\mathrm{K}_{2} \mathrm{HPO}_{4}$ & - & 1.5 & 2.0 & 2.0 & 1.5 \\
\hline $\mathrm{FeSO}_{4}$ & - & 0.01 & - & 0.01 & 0.01 \\
\hline $\mathrm{CaCO}_{3}$ & 2.0 & - & - & 0.02 & - \\
\hline $\mathrm{NaCl}$ & 5.0 & - & 5.0 & 2.0 & - \\
\hline $\mathrm{CaCl}_{2}$ & - & - & 0.4 & - & - \\
\hline $\mathrm{MnSO}_{4} \cdot \mathrm{H}_{2} \mathrm{O}$ & - & - & 0.1 & - & - \\
\hline $\mathrm{ZnCl}_{2}$ & - & - & 0.05 & - & - \\
\hline $\mathrm{FeCl}_{3} \cdot 6 \mathrm{H}_{2} \mathrm{O}$ & - & - & 0.1 & - & - \\
\hline $\mathrm{MgSO}_{4} \cdot 7 \mathrm{H}_{2} \mathrm{O}$ & - & - & 1.0 & 0.05 & - \\
\hline $\mathrm{KNO}_{3}$ & - & - & - & 2.0 & - \\
\hline $\mathrm{pH}$ & $6.7-7.0$ & 6.5 & 7.0 & $7.0-7.4$ & 6.5 \\
\hline
\end{tabular}

${ }^{1}$ Euromicin Production medium; ${ }^{2}$ Glycerol medium; ${ }^{3}$ Starch Casein medium; ${ }^{4}$ Soybean Hydrolyzed medium containing Glycerol.

\section{Culture media}

The Streptomyces strains selected by the filter paper disk method were then used to evaluate their ability to produce $\mathrm{CA}$ in flasks. For this purpose, the strains were transferred to the seed medium that had the following composition $(\mathrm{g} / \mathrm{L}$ distilled water) 15.0 glycerol, 10.0 bacto peptone, 10.0 malt extract, 1.0 yeast extract, $2.5 \mathrm{~K}_{2} \mathrm{HPO}_{4}$, $0.75 \mathrm{MgSO}_{4} 7 \mathrm{H}_{2} \mathrm{O}, 0.001 \mathrm{MnCl}_{2} 4 \mathrm{H}_{2} \mathrm{O}, 0.001 \mathrm{FeSO}_{4} 7 \mathrm{H}_{2} \mathrm{O}$, $0.001 \mathrm{ZnSO}_{4} 7 \mathrm{H}_{2} \mathrm{O}, 213$-(N-morpholino) propane sulfonic acid (MOPS) (Oritz et al., 2007). The inoculum and production media had the same composition, namely (in $\mathrm{g} / \mathrm{L}$ distilled water) 10.0 glycerol, 20.0 soybean flour (SF), 1.2 $\mathrm{K}_{2} \mathrm{HPO}_{4}, 0.001 \quad \mathrm{MnCl}_{2} 4 \mathrm{H}_{2} \mathrm{O}, 0.001 \quad \mathrm{FeSO}_{4} 7 \mathrm{H}_{2} \mathrm{O}, 0.001$ $\mathrm{ZnSO}_{4} 7 \mathrm{H}_{2} \mathrm{O}, 21$ MOPS (Maranesi et al., 2005). The $\mathrm{pH}$ of media was adjusted to 6.8 with $\mathrm{NaOH} 5 \mathrm{M}$ solution. All media were autoclaved at $121^{\circ} \mathrm{C}$ for $15 \mathrm{~min}$.

\section{Submerged culture conditions}

Cell fragments of Streptomyces spp. mycelia were withdrawn and cultivated in liquid culture medium for $96 \mathrm{~h}$. After determination of initial biomass concentration by dry weight, cells were lyophilized and stored in 10\% (v/v) glycerol. The seed culture was prepared by adding the lyophilized cells $(6.6 \mathrm{~g} / \mathrm{L}$ dry weight $)$ contained in a 
cryotube with glycerol to $25 \mathrm{~mL}$ of seed medium in 250 $\mathrm{mL}$-Erlenmeyer flasks that were incubated in an orbital shaker at $28{ }^{\circ} \mathrm{C}$ and $200 \mathrm{rpm}$ for $24 \mathrm{~h}$. Afterwards, 250 $\mathrm{mL}$-Erlenmeyer flasks containing $45 \mathrm{~mL}$ of inoculum medium were inoculated with $5.0 \mathrm{~mL}$ of the seed culture and incubated under the same conditions. Aliquots of this suspension $(5.0 \mathrm{~mL})$ with cells grown for $24 \mathrm{~h}$ were transferred to $250 \mathrm{~mL}$-Erlenmeyer flasks containing $45 \mathrm{~mL}$ of the above production medium. Submerged cultivations were performed at $200 \mathrm{rpm}$ at $28^{\circ} \mathrm{C}$ for $168 \mathrm{~h}$.

\section{Analytical methods}

The fermented broth was centrifuged at $5500 \mathrm{x} g$ for 20 min at $4{ }^{\circ} \mathrm{C}$, and the cell pellet was washed twice with distilled water and dried to constant weight at $80{ }^{\circ} \mathrm{C}$. Clavulanic acid concentration in the fermented broth was determined spectrophotometric ally by its reaction with imidazole (Bird et al., 1982). For this purpose, the increase in the optical density at $311 \mathrm{~nm}$ consequent to the formation of the product [1-(8-hydroxy-6-oxo-4-azooct-2-enol)-imidazole] was determined using a UV/Vis spectrophotometer, model Ultrospec 3000 pro (GE Healthcare, Life Sciences, Uppsala, Sweden). Glycerol concentration was determined according to Hae Bok and Demain (1977).

\section{Kinetic parameters}

The specific growth rate $\left(\mu_{\mathrm{x}}\right)$, expressed in $\mathrm{h}^{-1}$, was defined as:

$$
\mu_{x}=\frac{1}{t} \ln \frac{X}{X_{\mathrm{o}}}
$$

where $\mathrm{t}$ is the time (h) and $X$ and $X_{\mathrm{o}}$ are the cell concentrations $(\mathrm{g} / \mathrm{L})$ at time $t$ and at the beginning of the run, respectively.

The CA specific production rate $\left(\mu_{C A}\right)$, mean CA productivity $\left(P_{C A}\right)$ and yield of biomass on product $\left(Y_{X / P}\right)$, expressed in $\mathrm{h}^{-1}, \mathrm{mg} / \mathrm{L} . \mathrm{h}$ and dimensionless, respectively, were defined as:

$$
\begin{aligned}
& \mu_{C A}=\frac{1}{X} \frac{d C_{C A}}{d t} \\
& P_{C A}=\frac{C_{C A}}{t} \\
& Y_{X / P}=\frac{d X}{d T} \frac{d C_{C A}}{d t}
\end{aligned}
$$

where $C_{C A}$ is the maximum CA concentration $(\mathrm{mg} / \mathrm{L})$ at time $t$.

\section{Molecular identification}

The best Streptomyces CA producer, namely Streptomyces DAUFPE-3060, was submitted to DNA sequencing. Its DNA was extracted using the Wizard Geno- mic DNA Purification Kit (Promega, Madison, WI, USA) according to the manufacturer's instructions. Amplification of 16S DNA was performed by polymerase chain reaction using universal primers for eubacteria FD1 (5' AGAGTTTGATCCTGGCTCAG-3') and RD1 (5'-AAGGAGGTGATCCAGCC-3') (Weisburg et al., 1991). The reaction mixture was composed of 10 to $50 \mathrm{ng}$ of DNA, $5 \mathrm{p}$ moles of each primer, $200 \mathrm{mM}$ dNTP, $1.5 \mathrm{mM}$ $\mathrm{MgCl}_{2}, 1 \mathrm{X}$ buffer, $1 \mathrm{U}$ Platinum Taq DNA polymerase (Invitrogen Life Technologies, Carlsbad, CA, USA) to a final volume of $25 \mu \mathrm{L}$. The reaction took place with 5 min denaturation at $94^{\circ} \mathrm{C} ; 25$ cycles were carried out for $1 \mathrm{~min}$ at $94{ }^{\circ} \mathrm{C}, 30 \mathrm{~s}$ at $52^{\circ} \mathrm{C}$ and $2 \mathrm{~min}$ at $72{ }^{\circ} \mathrm{C}$. These cycles were followed by a final elongation period of $10 \mathrm{~min}$ at $72^{\circ} \mathrm{C}$. The amplification product was sequenced and the resulting sequence compared with others available in GenBank using the BLAST software from the National Center for Biotechnology Information (NCBI) website (http://www.ncbi.nlm.nih.gov/).

\section{Statistical analyses}

All the analyses and experiments were performed in triplicate, and the results expressed as mean values. The errors of experimental data from the mean values were expressed as standard deviations using the Microsoft Excel 2000 program (MapInfo Corporation, Troy, NY, USA) and illustrated as error bars.

\section{Results}

\section{Screening of producers of $\beta$-lactamase inhibitors}

In a first screening, the 19 Streptomyces isolates were cultivated in Starch Casein (SC) and ISP-2 agar media to select producers of $\beta$-lactamase inhibitors by the agar block method. Among these strains, 21\% (DAUFPE-3036, DAUFPE-3060, DAUFPE-3094, DAUFPE-3098 and DAUFPE-3133) showed antimicrobial activity in the SC medium and 16\% (DAUFPE-3060, DAUFPE-3133 and DAUFPE-3094) also in the ISP-2 medium. Table 2 shows the inhibition zone diameters obtained culturing these 5 strains in both media.

Table 2 - Results of antimicrobial activity tests of Streptomyces strains made in Starch Casein Agar (SCA) and ISP-2 media according to the agar block method.

\begin{tabular}{lcc}
\hline Strain & $\begin{array}{c}\text { Inhibition zone in } \\
\text { SCA medium }(\mathrm{mm})\end{array}$ & $\begin{array}{c}\text { Inhibition zone in } \\
\text { ISP-2 medium }(\mathrm{mm})\end{array}$ \\
\hline DAUFPE-3060 & 11 & 18 \\
DAUFPE-3133 & 11 & 19 \\
DAUFPE-3094 & 12 & 15 \\
DAUFPE-3036 & 0 & 37 \\
DAUFPE-3098 & 0 & 32 \\
\hline
\end{tabular}

*Maximum standard deviation estimated from triplicate experiments was $\pm 1 \mathrm{~mm}$. 
After this step, the 5 active strains of Streptomyces spp. were submitted to tests according to the filter paper disk method in different media in order to select the best producers of $\beta$-lactamase inhibitors. The results obtained from cultivations performed in SC, Euromicin Production (EP) and modified EP media are listed in Table 3. The strains that showed $\beta$-lactamaseinhibition activity were DAUFPE-3036 after $24 \mathrm{~h}$ and DAUFPE-3098 after $48 \mathrm{~h}$ of incubation, while the other three strains (DAUFPE-3060, DAUFPE-3133 and DAUFPE-3094) showed activity only in the EP medium. The best result as a whole were obtained after $72 \mathrm{~h}$ of incubation in the EP medium with the strain DAUFPE-3133 that exhibited an inhibition zone of $18 \mathrm{~mm}$.

\section{Biomass growth and clavulanic acid production}

The factors required for microbial growth can be divided into two classes, the physical and chemical. Physical factors include temperature, $\mathrm{pH}$ and osmotic pressure while chemical factors include sources of carbon, nitrogen, sulfur, phosphorus, oxygen, trace elements and growth factors (Tortora et al., 2012). Furthermore, according to SantosEbinuma et al. (2013) carbon and nitrogen sources may influence not only cell growth but also product formation. As in the present work different Streptomyces strains are being evaluated for their capacity to produce CA, it is important to select the best producer before carrying out studies devoted to optimization of conditions.

Figure 1A shows the results of growth of the five active Streptomyces strains (DAUFPE-3036, DAUFPE3060, DAUFPE-3094, DAUFPE-3133 and DAUFPE3098) and of Streptomyces clavuligerus ATCC 27064 (control) during submerged cultures in flasks for $168 \mathrm{~h}$. The exponential phase was detected for all strains between 24 and $72 \mathrm{~h}$; however, whereas DAUFPE-3133, DAUFPE3094, DAUFPE-3060, DAUFPE-3098 and ATCC 27064 did not exhibit any lag phase and quickly reached the exponential one, DAUFPE-3036 took a comparatively long adaptation period and displayed a short exponential phase. This situation was the likely result of premature microbial growth already in the inoculum medium and subsequent withdrawal of a portion of biomass to inoculate the production medium.

The results of CA production by the 5 Streptomyces isolates and the control strain are illustrated in Figure 1B. The best producer was DAUFPE-3060 that accumulated no less than $575 \mathrm{mg} / \mathrm{L} \mathrm{CA}$ after $96 \mathrm{~h}$ and then showed a progressive decrease in CA concentration. Such production was $22 \%$ higher than that observed with the control strain after $120 \mathrm{~h}$ and much higher than those achieved with the other strains.

\section{Kinetic study}

Although kinetic modeling is essential to estimate costs of an optimized bioprocess as well as to develop control strategies (Baptista-Neto et al., 2000), there are only a few papers in the literature dealing with the kinetics of CA production $v s$. growth; therefore, it was one of the issues investigated in this study.

Consistently with the above results of CA production, the best producer showed also the highest CA productivity $(5.99 \mathrm{mg} / \mathrm{L} \mathrm{h})$ after $96 \mathrm{~h}$ of cultivation (Figure 2), while DAUFPE-3133 and DAUFPE-3036 exhibited the lowest values (1.63 and $1.78 \mathrm{mg} / \mathrm{L} \mathrm{h}$, respectively), and the control strain a value close to that ofDAUFPE-3060 (5.66 mg/L h).

As shown in Figure 3, the DAUFPE-3098 and the control strain showed the lowest maximum specific rates of CA formation $\left(\mu_{C A}\right)$. Although a higher value of this kinetic parameter was obtained with the strain DAUFPE-3036 $\left(2.01 \mathrm{~h}^{-1}\right)$, the overall performance of DAUFPE-3060 should be considered the best one being able to ensure almost the same $\mu_{C A}$ value $\left(1.96 \mathrm{~h}^{-1}\right)$ but in quarter the time (24 instead of $96 \mathrm{~h}$ ). In contrast with the other strains that suffered a progressive decrease of $\mu_{C A}$ with time, DAUFPE- 3133 showed lower $\mu_{C A}$ after $72 \mathrm{~h}$ of cultivation and reached a maximum value of $1.39 \mathrm{~h}^{-1}$ after $120 \mathrm{~h}$, likely due to both an increase in cell concentration and a CA degradation during the run. Taking all results together, $\mu_{C A}$ varied from $0.06 \mathrm{~h}^{-1}$ (standard strain after $144 \mathrm{~h}$ ) to $2.01 \mathrm{~h}^{-1}$

Table 3 - Results of antimicrobial activity tests of Streptomyces strains made in Starch Casein (SC), Euromicin Production (EP) and modified EP media according to the filter paper disk method.

\begin{tabular}{lcccc}
\hline Strain & Time $(\mathrm{h})$ & $\begin{array}{c}\text { Inhibition zone in SC } \\
\text { medium }(\mathrm{mm})^{*}\end{array}$ & $\begin{array}{c}\text { Inhibition zone in EP } \\
\text { medium }(\mathrm{mm}) *\end{array}$ & $\begin{array}{c}\text { Inhibition zone in modified EP } \\
\text { medium (mm)* }\end{array}$ \\
\hline DAUFPE-3060 & 48 & - & 14 & 17 \\
DAUFPE-3133 & 72 & - & 18 & - \\
DAUFPE-3094 & 72 & - & 16 & 12 \\
DAUFPE-3036 & 24 & 10 & - & - \\
DAUFPE-3036 & 48 & - & - & 13 \\
DAUFPE-3098 & 48 & 9 & - & 15 \\
\hline
\end{tabular}

* Maximum standard deviation estimated from triplicate experiments was $\pm 1 \mathrm{~mm}$. 



Figure 1 - Time behavior of biomass (A) and clavulanic acid (B) concentrations along 168 h-submerged cultures of Streptomyces DAUFPE-3133, DAUFPE-3098, DAUFPE-3060, DAUFPE-3094, DAUFPE-3036 and Streptomyces clavuligerus ATCC 27064.



Figure 2 - Time behavior of clavulanic acid productivity along 168 h-submerged cultures of different Streptomyces strains. Time (h): 24; 48, 72, 96, 120, $144168 \mathrm{~h}$.

(DAUFPE-3036 after $96 \mathrm{~h}$ ). These specific productivities are higher than that reported by Elibol and Mavituna (1999) for the actinorhodin production by Streptomyces coelicolor in bioreactor.

As it can be observed in Table 4, the strains DAUFPE-3060 and DAUFPE-3098 had the highest specific growth rate $\left(\mu_{\mathrm{x}}=0.062 \mathrm{~h}^{-1}\right.$ for both) after $48 \mathrm{~h}$, while the control strain grew about $8 \%$ less quickly.
Figure 4 shows that the highest values of the yield of growth on product $\left(\mathrm{Y}_{X / P}\right)$ were obtained within $24 \mathrm{~h}$ with DAUFPE-3098 (0.15) and DAUFPE-3036 (0.11), both preferring to grow rather than to produce $\mathrm{CA}$, while, as expected, the opposite took place with the best CA producer and the control strain $\left(\mathrm{Y}_{X / P}=0.05\right.$ for both). Even lower yields were obtained with the other strains due to a too slow growth in addition to a poor production. 


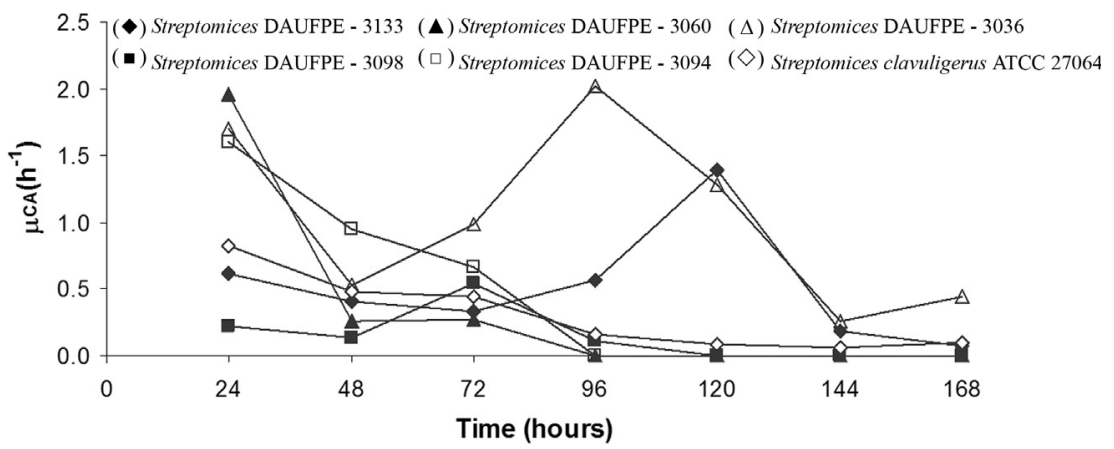

Figure 3 - Time behavior of specific clavulanic acid productivity $\left(\mu_{C A}\right)$ along $168 \mathrm{~h}$-submerged cultures of Streptomyces DAUFPE-3133, DAUFPE3098, DAUFPE-3060, DAUFPE-3094, DAUFPE-3036 and Streptomyces clavuligerus ATCC 27064.

Table 4 - Specific growth rate of different Streptomyces isolates and S. clavuligerus ATCC 27064 (control strain) during submerged cultures.

\begin{tabular}{lcccccc}
\hline Time (h)/strain & $\begin{array}{c}\text { DAUFPE-3133 } \\
\left(\mathrm{h}^{-1}\right)\end{array}$ & $\begin{array}{c}\text { DAUFPE-3098 } \\
\left(\mathrm{h}^{-1}\right)\end{array}$ & $\begin{array}{c}\text { DAUFPE-3060 } \\
\left(\mathrm{h}^{-1}\right)\end{array}$ & $\begin{array}{c}\text { DAUFPE-3094 } \\
\left(\mathrm{h}^{-1}\right)\end{array}$ & $\begin{array}{c}\text { DAUFPE-3036 } \\
\left(\mathrm{h}^{-1}\right)\end{array}$ & $\begin{array}{c}\text { ATCC 27064 } \\
\left(\mathrm{h}^{-1}\right)\end{array}$ \\
\hline 48 & 0.049 & 0.062 & 0.062 & 0.040 & 0.039 & 0.057 \\
72 & 0.038 & 0.038 & 0.040 & 0.032 & 0.017 & 0.036 \\
96 & 0.026 & 0.025 & 0.025 & 0.018 & 0.006 & 0.026 \\
120 & 0.021 & 0.019 & 0.019 & 0.013 & 0.003 & 0.020 \\
144 & 0.017 & 0.016 & 0.014 & 0.011 & 0.006 & 0.016 \\
168 & 0.014 & 0.014 & 0.013 & 0.010 & 0.005 & 0.014 \\
\hline
\end{tabular}

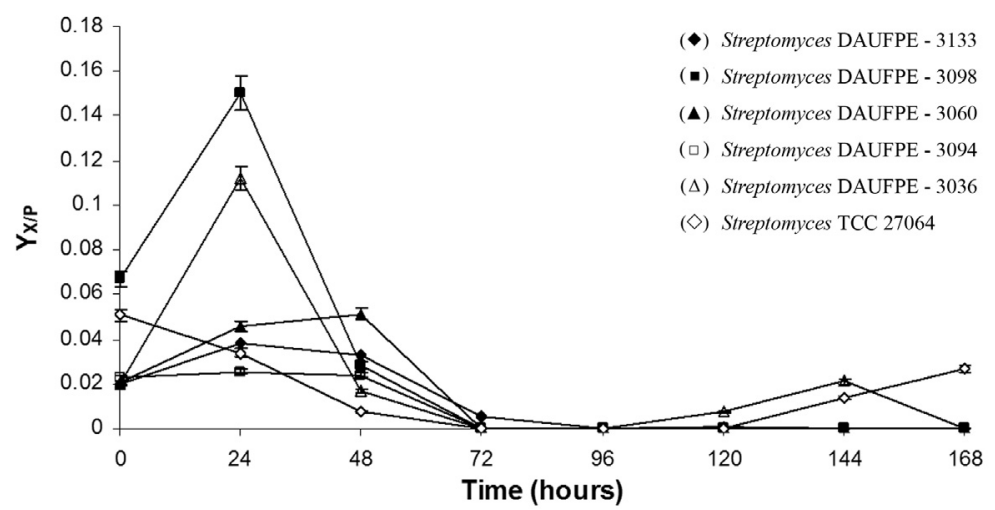

Figure 4 - Time behavior of the yield of growth on product $\left(Y_{X / P}\right)$ along 168 h-submerged cultures of Streptomyces DAUFPE-3133, DAUFPE-3098, DAUFPE-3060, DAUFPE-3094, DAUFPE-3036) and Streptomyces ATCC 27064.

\section{Molecular identification of the best CA producer}

Molecular identification was finally performed for DAUFPE-3060 that behaved as the best CA producer. The $1550 \mathrm{bp}$ sequenced fragment showed $96 \%$ identity with the strain Streptomyces variabilis 7525 (accession number: gi|341793371|JN180216.1); so, it was identified as the action bacterium Streptomyces variabilis DAUFPE 3060.

\section{Discussion}

In this study, we tested different Streptomyces strains in order to find a novel and alternative microorganism able to overproduce $\mathrm{CA}$, for which distinct media were investigated (Figure 1). The results obtained with EP and modified EP media were quite different, in that the CA production was considerably quicker in the latter medium, where the antimicrobial activity was observed only after $12 \mathrm{~h}$ of incubation with all the strains studied. The diameter of the inhibition zone made from samples collected between 12 and $24 \mathrm{~h}$ ranged from 13 to $17 \mathrm{~mm}$ with DAUFPE-3036, 3060, 3094 and 3098, but it considerably decreased after $48 \mathrm{~h}$. Sometimes, a decrease in activity was observed after 48 $72 \mathrm{~h}$ probably due to degradation of CA released during the 
submerged culture. For instance, Chen et al. (2003) reported that a decrease in CA concentration after $36 \mathrm{~h}$ of $S$. clavuligerus submerged culture was the likely consequence of increasing $\mathrm{pH}$ and cell autolysis, and similar occurrence was observed by Mayer and Deckwer (1996) and Romero et al. (1984) with $S$. clavuligerus and by Viana Marques et al. (2009) with Streptomyces DAUFPE-3060. The strains DAUFPE-3094, DAUFPE-3036 and DAUFPE-3060 exhibited positive response with inhibition zones narrower than $10 \mathrm{~mm}$ in Soybean Hydrolyzed medium with Glycerol (SHG). These results suggest that the other strains (DAUFPE-3133 and DAUPE-3098) probably preferred glucose as carbon source to grow.

Resuming, this part of the study pointed out different behaviors of the five strains possessing $\beta$-lactamase inhibition activity, all of them being able to produce $\mathrm{CA}$ in the $\mathrm{EP}$ medium, DAUFPE-3036, DAUFPE-3060 and DAUFPE3094 also in the modified EP and SHG media, and DAUFPE-3098 in the former.

Considering biomass growth and CA production, all the strains reached maximum biomass concentration (4$12 \mathrm{~g} / \mathrm{L}$ ) after $48 \mathrm{~h}$ of cultivation, with the exception of the strains DAUFPE-3133 and DAUFPE-3094 that lasted longer $(72 \mathrm{~h})$. These times were relatively short taking into account that the exponential phase of Streptomycetes usually stops after 96 h (Viana et al., 2010; Viana Marques et al., 2011) and that all these submerged cultures were performed in flasks, i.e. under non-optimized conditions. Bushell et al. (2006) studied the CA production by $S$. clavuligerus NRRL 3585 in $2.5 \mathrm{~L}$ bioreactor and obtained a biomass concentration of $5 \mathrm{~g} / \mathrm{L}$ within $150 \mathrm{~h}$. A similar result was obtained after $72 \mathrm{~h}$ by Gouveia et al. (1999) with S. clavuligerus NRRL 3585 in a medium enriched with amino acids. Viana et al. (2010) reported for DAUFPE-3060 a maximum CA production of $494 \mathrm{mg} / \mathrm{L}$ after $48 \mathrm{~h}$ and a subsequent CA consumption after glycerol depletion in the medium using soybean proteins. Lower CA concentration (338 mg/L after $108 \mathrm{~h}$ ) was reported for S. clavuligerus ATCC 27064 submerged culture in flasks using soy protein as nitrogen source and soybean oil and glycerol as carbon sources (Ortiz et al., 2007); however, Costa and Badino (2012) achieved no less than $1543 \mathrm{mg} / \mathrm{L}$ with the same microorganism using pulses of glycerol at constant temperature $\left(20^{\circ} \mathrm{C}\right)$.

A literature survey reveals that the nitrogen source has a strong influence on CA production by $S$. clavuligerus. A comparison of the results obtained in the present work in flasks using a cheap nitrogen source like soybean flour with those reported in the literature using proline and glutamic acid (Romero et al., 1984), malt extract and bacteriological peptone (Belmar-Beiny and Thomas, 1991), soy extract and peptone from meat (Mayer and Deckwer, 1996), soybean extract and bacteriological peptone (Gouveia et al., 1999) and Samprosoy (Teodoro et al., 2006) stands out
DAUFPE-3060 as a promising CA producer at an industrial level.

All the strains quickly grew in the first hours of submerged culture. Similar results were obtained by Saudagar and Singhal (2007), who studied the influence of different amino acids as nitrogen source on CA production by $S$. clavuligerus and found $\mu_{\mathrm{x}}$ values of 0.057 and $0.055 \mathrm{~h}^{-1}$ using arginine and threonine, respectively. Kim and Lee (1995) studying the continuous production of leupeptin (a protease inhibitor) by Streptomyces exfoliatus SMF13 obtained $\mu_{\mathrm{x}}=0.08 \mathrm{~h}^{-1}$ and a productivity as high as $0.24 \mathrm{~g} / \mathrm{L} . \mathrm{h}$ between 48 and $72 \mathrm{~h}$ of cultivation. A $\mu_{\max }$ of $0.207 \mathrm{~h}^{-1}$ was reported by Baptista Neto et al. (2000) for CA production by S. clavuligerus NRLL 3585 in bioreactor using peptone and Samprosoy 90 NB as nitrogen sources, which suggests the potential of future optimization of our process at least in a bench-scale fermenter. In general, the large variability of $Y_{X / P}$ observed in this study under all the conditions tested is the result of the well-known presence of two separate phases of growth (trophophase) and production (idiophase).

\section{Conclusions}

A screening study was made, which suggested that clavulanic acid production could be greatly improved using new strains of Streptomyces. Five new isolates with $\beta$-lactamase inhibiting activity screened in this study showed potential to be used as CA producers; however, the strain DAUFPE-3060 showed the best results and was subsequently identified as the novel actinobacterium Streptomyces variabilis DAUFPE 3060. Thus, further optimization studies devoted to possible industrial exploitation are of great interest. This strain did in fact show a $28 \%$ increase in CA production compared to S. Clavuligerus ATCC 27064 (control strain). Soybean flour was shown to be an interesting alternative nitrogen source for $\mathrm{CA}$ production, being cheaper than others reported in the literature. Therefore, its use is expected to substantially reduce the production cost of such a $\beta$-lactamase inhibitor.

\section{Acknowledgments}

The authors gratefully acknowledge the financial support of the Brazilian Research Funding Institution FAPESP (Process n. 05/60158-0).

\section{References}

Bailey JE, Ollis DF (1986) Biochemical Engineering Fundamentals. 2nd. ed. McGraw-Hill, New York.

Baptista-Neto A, Gouveia A, Gouveia ER, Badino Jr AC, Hokka CO (2000) Phenomenological model of the clavulanic acid production process utilizing Streptomyce sclavuligerus. Braz J Chem Eng 17:4-7.

Belmar-Beiny MT, Thomas CR (1991) Morphology and clavulanic acid production of Streptomyces clavuligerus: Effect 
of stirrer speed in batch fermentation. Biotechnol Bioeng 37:456-462.

Bird AE, Bellis JM, Gasson BC (1982) Spectrophotometric assay of clavulanic acid by reaction with imidazole. Analyst 107:1241-1245.

Brass JM, Hoeks FW, Rohner M (1997) Applications of modelling techniques for the improvement of industrial bioprocess. J Biotechnol 59:63-72.

Brown AG, Butterworth D, Cole M, Hanscomb G, Hood LD, Reading C, Rolinson GN. (1976) Naturally occurring betalactamases inhibitors with antibacterial activity. J Antibiot 29:668-669.

Bush K, Jacoby GA, Medeiros AA (1995) A functional classification scheme for $\beta$-lactamases and its correlation with molecular structure. Antimicrob Agents Ch 3:1211-1233.

Bushell ME, Kirk S, Zhao HJ, Avignone-Rossa CA (2006) Manipulation of the physiology of clavulanic acid biosynthesis with the aid of metabolic flux analysis. Enzyme Microb Technol 39:149-157.

Butterworth D (1984) Clavulanic acid: Properties Biosynthesis, and Fermentation. In: Vandamme, E.J. (ed) Biotechnology of Industrial Antibiotics. New York, Marcel Dekker, vol. 22, pp. 225-235.

Chen QH, He GQ, Mokhtar AMA (2002) Optimization of medium composition for the production of elastase by Bacillus sp. EL31410 with response surface methodology. Enzyme Microb Technol 30:667-672.

Chen KC, Lin YH, Wu JY, Hwang SCJ (2003) Enhancement of clavulanic acid production in Streptomyces clavuligerus with ornithine feeding. Enzyme Microb Technol 32:152156.

Costa CLL, Badino AC (2012) Production of clavulanic acid by Streptomyces clavuligerus in batch cultures without and with glycerol pulses under different temperature conditions. Bioch Eng J 69:1-7.

Efthimiou G, Thumser AE, Avignone-Rossa CA (2008) A novel finding that Streptomyces clavuligerus can produce the antibiotic clavulanic acid using olive oil as a sole carbon source. J Appl Microbiol 105:2058-2064.

Elibol M, Mavituna F (1999) A remedy to oxygen limitation in antibiotic production: Addition of perfluorocarbon. Biochem Eng J 3:1-7.

Gouveia ER, Baptista-Neto A, Azevedo AG, Badino AC, Hokka CO (1999) Improvement of clavulanic acid by Streptomyces clavuligerus in medium containing soybean derivative. World J Microb Biot 15:623-627.

Gouveia ER, Baptista-Neto A, Badino Jr AC, Hokka CO (2001) Optimisation of medium composition for clavulanic acid production by Streptomyces clavuligerus. Biotechnol Lett 23:157-161.

Hae Bok S, Demain AL (1977) An improved colorimetric assay for polyols. Anal Biochem 81:18-20.

Hassan M, Kjos M, Nes IF, Diep DB, Lotfipour F. (2012) Natural antimicrobial peptides from bacteria: characteristics and potential applications to fight against antibiotic resistance. J Appl Microbiol 113:723-736.

Kim IS, Lee KJ (1995) Kinetic study on the production and degradation of leupeptin in Streptomyces exfoliatus SMF13. J Biotechnol 42:35-44.

Kirk S, Avignone-Rossa CA, Bushell ME (2000) Growth limiting substrate affects antibiotic production and associated meta- bolic fluxes in Streptomyces clavuligerus. Biotechnol Lett 22:1803-1809.

Lee PC, HO CC (1996) Production of clavulanic acid and cephamycin C by Streptomyces clavuligerus in palm-oil medium. World J Microb Biot 12:73-75.

Liras P, Martín JF (2009) $\beta$-Lactam Antibiotics. Encyclopedia of Microbiology. 3rd ed. pp 274-289.

Maranesi GL, Baptista-Neto A, Hokka CO, Badino-Jr AC (2005) Utilization of vegetable oil in the production of clavulanic acid by Streptomyces clavuligerus ATCC 27064. World J Microb Biotechnol 21:509-514.

Mayer AF, Deckwer WD (1996) Simultaneous production and decomposition of clavulanic acid during Streptomyces clavuligerus cultivations. Appl Microbiol Biot 45:41-46.

Mounir MS, Fars KA, Ibrahim AA (2010) Improvement and enhancement of clavulanic acid production in Streptomyces clavuligerus using vegetable oils. Afr J Biotechnol 9:68066812.

Ortiz SCA, Hokka CO, BadinoJr AC (2007) Utilization of soybean derivatives on clavulanic acid production by Streptomyces clavuligerus. Enzyme Microb Technol 40:1071-1079.

Pridham TG, Gottlieb D (1948) The utilization of carbon compounds by some Actinomycetales: as an aid for species determination. J Bacteriol 56:107-114.

Pridham TG, Anderson P, Foley C, Lindenfelser LA, Hesseltine CW, Benedict RG (1957) A selection of media for maintenance and taxonomic study ofStreptomyces. Antibiot Annu 947-95.

Pruess DL, Kellett M (1983) A new clavam antibiotic from Streptomyces clavuligerus. J Antibiot 36:208-212.

Romero J, Liras P, Martín JF (1984) Dissociation of cephamycin and clavulanic acid biosynthesis in Streptomyces clavuligerus. Appl Microbiol Biot 20:318-325.

Santos VC, Hasmann FA, Converti A, Pessoa Jr A (2011) Liquid-liquid extraction by mixed micellar systems: A new approach for clavulanic acid recovery from fermented broth. Biochem Eng J 56:75-83.

Santos-Ebinuma VC, Teixeira MFS, Pessoa Jr A (2013) Submerged Culture Conditions for the Production of Alternative Natural Colorants by a New Isolated Penicillium purpurogenum DPUA 1275. J Microbiol Biotechnol 23:802-810.

Saudagar PS, Singhal RS (2007) Optimization of nutritional requirements and feeding strategies for clavulanic acid production by Streptomyces clavuligerus. Bioresource Technol 98:2010-2017.

Silva CS, Cuel MF, Barreto VO, Kwong WH, Hokka CO, Barboza M (2012) Separation of clavulanic acid from fermented broth of amino acids by an aqueous two-phase system and íon-exchange adsorption. New Biotech 29:428-431.

Spratt BG (1994) Resistance to antibiotics mediated by target alterations. Science 264:388-393.

Taddei A, Rodriguez MJ, Marquez-Vilchez E, Castelli C (2005) Isolation and identification of Streptomyces spp. from Venezuelan soils: morphological and biochemical studies. Microbiol Res 161:222-231.

Tarbuck LA, Ng MH Leigh JR, Tampion J (1985) Estimation of the progress of Streptomyces clavuligerus submerged culture for improved on-line control of antibiotic production, In: Johnson, A. (ed) Modelling and Control of Biotechnological Process. Pergamon, Oxford, pp 171-178. 
Teodoro JC, Baptista-Neto A, Cruz-Hérnandez IL, Hokka CO, Badino AC (2006) Influence of feeding conditions on clavulanic acid production in fed-batch cultivation with medium containing glycerol. Appl Microbiol Biot 72:450-455.

Tortora GJ, Funke BR, Case CL (2012) Microbiologia. 10 ed. Artmed, Porto Alegre, pp. 157.

Viana DA, Carneiro-Cunha MN, Araújo JM, Barros-Neto B, Lima-Filho JL, Converti A, Pessoa Jr A, Porto AL (2010) Screening of variables influencing the clavulanic acid production by Streptomyces DAUFPE 3060 strain. Appl Biochem Biotechnol 160:1797-1807.

Viana Marques DA, Oliveira RPS, Perego P, Porto ALF, Pessoa Jr A, Converti A (2009) Kinetic and thermodynamic investiga- tion on clavulanic acid formation and degradation during glycerol fermentation by StreptomycesDAUFPE 3060. Enzyme Microb Technol 45:169-173.

Viana Marques DA, Carneiro-Cunha MN, Araújo JM, Lima-Filho JL, Converti A, Pessoa Jr A, Porto ALF (2011) Optimization of clavulanic acid production by Streptomyces DAUFPE 3060 by response surface methodology. Braz J Microbiol 42:658-667.

Weisburg WG, Barns SM, Pelletier DA, Lane DJ (1991) 16S ribossomal DNA amplification for phylogenetic study. J Bacteriol 2:697-703.

All the content of the journal, except where otherwise noted, is licensed under a Creative Commons License CC BY-NC. 